\title{
The Necktie
}

\section{Tsering Döndrup, translated by Chris Peacock}

\begin{abstract}
ome say this thing called the necktie evolved from the scarves worn by cart drivers in Europe, while some sources claim that it Was first introduced to France by a group of Croatian mercenaries. Regardless of its lowly origins, and regardless of the amount of acclaim or contempt it may have garnered, it's fair to say that in the modern era this thin strip of soft, brilliant cloth has added a magnificent splash of color to men's otherwise drab outfits, like wild flowers blooming on the grasslands. But from its first arrival in Tsezhung through to the present day, the necktie has a history of no more than twenty years. I can personally attest to this piece of history, because it was none other than I who first brought the necktie to the region of Tsezhung.
\end{abstract}

It was a summer some ten-plus years ago, the kind so beautiful it can't help but bring tears to your eyes. I had just graduated from a university off in the east of China and had returned to my homeland, the grasslands of Tsezhung. At the time, I basically had nothing to my name other than a cheap Western suit with a colorful silk tie, a box of literary texts that would soon prove to be completely useless, a few short poems I had published in some magazines, and a delightful, utterly ridiculous sounding nickname - "The Poet." Nevertheless, I was feeling bright and cheery, because I would soon be bringing in a monthly salary.

I was assigned to a department that had no connection whatsoever to my major of language and literature. The head of the department was a harsh but fair (something I was to learn later) man in his mid-40s. The first time I went to meet him I was terrified, and I thought he was, too, because his eyes went round as plates and he sat there pointing at my chest for what felt like an age, unable to utter a word. I realized that he was even trembling a little.

"Take... take that thing off your neck!" After a long pause, he added: "What the hell!"

I finally realized that he was talking about my tie. Just you think about it for a second - how could a young man with a glorious title like "The Poet" bow down to some country bumpkin, even if it meaning losing his job? Needless to say, my magnificent necktie was going nowhere. 
Later on, every time he complained about my tie, I recited that great Chekhov quote to myself in my head: "Everything about a person should be first-rate: his thoughts, his clothes, his..."

Following the example set by me, the number of people wearing Western suits and ties in Tsezhung grew and grew.

Around here, however, there's a still big mix of men who've cut off their traditional braids and men who haven't, and for a time people didn't know quite how to treat this foreign import. Some people tied their ties onto the collar of a tracksuit jacket then put a Mao suit on over the top. Some people donned their Western suits and their ties and then topped it off with a green army cap. Some people wrapped their ties around their necks and tied a knot so tight they almost choked to death. Even the lama Alak Drong, whose fame spread far and wide, adopted a yellow tie which he wore beneath a string of ivory prayer beads, then completed his look with a dark brown leather jacket. I thought it looked completely absurd, but the local sycophants all said that the "style of the reverend lama's garments is rich with ethnic characteristics!", which pleased Alak Drong no end. I have no doubt that if the Buddha had stuck around for 2,500 years to witness our modern age and see the state of his disciple, he'd be absolutely aghast.

What surprised me was that my boss finally started wearing a tie. He didn't really know how to tie it properly, but from a distance, at least, he looked a lot more impressive. What surprised me even more was that one time I happened to come across him sleeping shirtless but with the tie still on. When I asked him what was going on, he replied quite candidly that someone had helped him tie a good knot and if he undid it he wouldn't be able to tie it again. $A b$ kha, heaven really knows how to play with people, I thought to myself.

Now it's some ten years later, and I was never able to carve out a career for myself as a poet, but I have become a junior manager at the office - I've turned into what I used to think of as a "country bumpkin." Whether it's because I'm too busy or because I'm getting on in years I don't know, but either way I've been paying less and less attention to my appearance in recent years. Much to my surprise, I actually ended up getting in trouble again because of this. Yesterday morning when I first got into the office, that harsh but fair boss of mine sized me up and said, "The higher ups are coming to do an inspection today, surely you didn't forget? What sort of way is this to show your respect, not even wearing a tie? What the hell!' 


\section{Works Cited}

Tshe ring don grub. "Gong dkris." In Tshe ring don grub kyi sgrung thung gsar ba bdams bsgrigs [A Collection of Tsering Döndrup's New Short Fiction], 120-124. Lanzhou: Kan su'u mi rigs dpe skrun khang, 2010. 